\author{
R.N. Nurdillayeva ${ }^{1}$, A.Zh. Baisalova ${ }^{2}$, G.O. Zhuman ${ }^{1}$ \\ ${ }^{1}$ Khoja Akhmet Yassawi International Kazakh-Turkish University, Turkistan, Kazakhstan; \\ ${ }^{2}$ Kazakh-Turkish boarding school No. 2 of the Education Department of the Karaganda region, Karaganda, Kazakhstan, \\ (E-mail: raushan.nurdillayeva@ayu.edu.kz)
}

\title{
Features of teaching Chemistry in English: continuity of traditional and new technologies
}

\begin{abstract}
The article describes the study results of the continuity of traditional and new technologies in teaching chemistry in English in secondary schools. In the study, alongside a variety of traditional methods, the CLIL method, Content and Language Integrated Learning was explored to enhance pupils' interest in chemistry and to improve their knowledge. Special attention was drawn to the learners' motivation, knowledge level and English language proficiency during the study of chemistry. The ways to apply new approaches towards teaching chemistry in English were considered and the practice of integrating chemistry and English on the basis of a new curriculum was studied. Terminology, glossary, English language-based text work and calculation methodology were selected for the classroom use of CLIL technology. At chemistry lesson pupils were surveyed and a pedagogical observation was performed to determine the effectiveness of using CLIL technology. According to the survey results the effectiveness of teaching chemistry in English was proven. Working on terminology and glossary the learners' interest in the subject was increased by using chemistry terminology in the classroom. The use of CLIL approach is based on integrating language in teaching the subject content allowed the pupils not only to gain information about the subject but also to master the language.
\end{abstract}

Keywords: CLIL method, teaching chemistry in English, Content and Language Integrated Learning, glossary, terminology, English language based text, CLIL technology, a survey, traditional method.

\section{Introduction}

Nowadays the development of the future generation as an intellectual person and multilingual education is an actual issue in the education system. The educational activity results of the implementation of the interdisciplinary connections are manifested in the expansion of pupils' knowledge of universal character, the substantive content aspect enrichment of foreign language communication, their learning motivation increase, individual development, self-education, and self-improvement.

The education system is improving and opening new horizons in accordance with modern requirements. Consequently, this is a renewal of secondary education content. This requires the development and implementation of an education program allowing the gradual transition to a competency-based teaching model and the application of non-traditional methods and forms of teaching organization, as well as the integrated teaching of various disciplines. First and foremost, the consideration of interdisciplinary connections development in the integrated teaching classroom is of paramount importance. Teaching language and subject content in an interdisciplinary connection creates many opportunities for the development of cognitive tasks, suggestions and the realization of learners' creative potential [1].

In the context of teaching natural science disciplines, English is regarded as the most important language in Kazakhstan since it forms the basis of the integrated teaching. The introduction of English into the integrated teaching process is primarily focused on learners' academic development during lessons and opportunities to strengthen teaching taking into consideration their psychological conditions.

Several recent studies have considered the importance of investigation of integrated English teaching. In their studies, G.I. Belyaeva, E.A. Samrodova, O.V. Voron, and E.S. Zakirova have described the integrated teaching methods of foreign languages for special purposes and analyzed their effectiveness. According to the study result, in the opinion of the humanitarian specialty students, discussions, ICT (information and communication technology) and SCRUM (framework that helps groups to work together and encourages team to learn through on a problem) were found to be the most effective methods of teaching foreign languages for special purposes, while debates, ICT and round table discussions were estimated as the best ones in conformity with the opinions of the teachers interviewed. According to the students' opinion, the «dilemma» method was determined to be inefficient, while the CLIL (Content and Language Integrated Learning) method was found to the most ineffective one by teachers [2]. This means that the CLIL methodology has not been fully investigated 
and needs to be improved. The results of the scientific literature analysis show that in modern educational practice the most widely applied methods integrating English with traditional methods are project method [3,4], case study [5, 6], brainstorming [7, 8], role method [9], round table [10], audio-linguistic method [11], content and language of integrated learning (CLIL method) $[12,13]$.

Researchers have shown that the CLIL method provides a number of benefits to students, and its success depends on the context in which the method is applied. In secondary schools, the research results were proved to be effective, the CLIL method was found to have no negative effect on pupils' English language proficiency, L1 level, and subject knowledge; this, in turn, encourages pupils to become more active in the learning process. The global need for language teaching, especially English, has given rise to the necessity of new approaches towards language teaching. The CLIL method is a flexible and efficient way of responding to the needs [14]. Teaching a subject content integrating with English has aroused great interest in Kazakhstan, as the CLIL method is expected to improve students' fluency in the English language and to impact on better preparation for their future careers.

In her study, D. Recatala conducted works aimed at combining active methods of teaching introduced to the physical chemistry course in a higher education institution in Spain, as well as integrating the subject content in this discipline with the English language. In this study, a number of factors that influence the world practice of teaching including the active teaching and the CLIL method in the physical chemistry class were analyzed. Some examples of these include views related to the discipline, interest and motivation in the course, attitudes towards the English language acquisition and overall students' satisfaction with the learning process [15]. In their works, B.A. Zhetpisbayeva and A.E. Kubeeva emphasized the effectiveness of using internationally recognized CLIL technology and focused on the relevance of learning and mastering the technology by future professional teachers. The essence of the Kazakh trilingual education model is the possibility of further development of the trilingual education ideas of the CLIL technology in the educational process. There are also survey results of higher education institution students and teachers who introduced trilingual education into the learning process [16].

Despite the comprehensive description of the importance and benefits of integrated teaching in English, the methods of teaching chemistry have been rarely studied. In this regard, to study the methodological basis of teaching chemistry in English is of great importance.

The main purpose of the proposed study is to build students' knowledge and skills based on the continuity of traditional teaching and new methods by taking into consideration the importance of teaching chemistry in English in secondary schools. The research tasks are the effective application of new methods and techniques in teaching chemistry based on the new curriculum; to illustrate and describe new methods, effective techniques of teaching chemistry in English; the formation of pupils' knowledge and interest; the development of learners' scientific vocabulary and the vocabulary related to the chemistry science.

\section{Experimental}

The pedagogical experiment of teaching chemistry in English was conducted among the $8^{\text {th }}$-grade pupils of the specialized boarding school named after N. Ondasynov in Turkestan.

In the first lesson, the main attention was paid to chemistry rather than English. Therefore, the simple terminology of the most common terms used during the chemistry class was applied.

Despite the fact that the textual work is one of the most significant ways in Content and Language Integrated Learning both in terms of learning objectives and language objectives, all types of classroom activities were applied in the lesson planning. When selecting the study material, original texts with a variety of styles were selected to meet the pupils' age requirements and language proficiency level. In teaching chemistry in English, the relevance of teaching terminology, glossary, work on the text composed on the English language basis and calculations were explored through the continuity of the CLIL method and traditional teaching methods.

A lot of work was accomplished on the terminology in teaching chemistry to stimulate the pupils' interest. The assignments were given to test previously obtained knowledge and for the acquisition of new knowledge. The new CLIL technology was used in continuity with traditional methods, brainstorming and «Five Ws» method to consider the significance of terminology in teaching chemistry in English. The terminology effectiveness was defined by the questionnaire taken from the pupils after the completion of the following tasks: The «brainstorming» method was applied to consolidate the topic that was covered at the beginning of the lesson:

1. Define the concepts of protons, neutrons, electrons in English. 
2. Write the words that correspond to the chemical bond.

Water; Bond; Electron; Chemistry; Ionic; Flask; Filter; Book; Shell; Matter.

3. Find names of metals and write them below

1. O; 2. Zn; 3. Si; 4. Hg; 5. C; 6. Fe; 7. Ca; 8. Ne; 9. Na; 10. Cl.

4. Write the symbols of the elements in 3 languages and calculate proton, electron, and neutron numbers $\mathrm{Al}, \mathrm{Cl}, \mathrm{F}, \mathrm{Fe}, \mathrm{Zn}, \mathrm{O}, \mathrm{H}, \mathrm{P}, \mathrm{Ca}, \mathrm{Na}, \mathrm{K}, \mathrm{Ag}$.

This method contributed to the pupils' knowledge acquisition speed and the accumulation of English language knowledge. Due to this, they could easily find the chemical elements names and became more active in the classroom.

«Five Ws» method is a method in which questions are asked in English by pupils in the classroom to increase their comprehension of the topic and to develop their discussion skills.

1. Students answered in English the questions which were asked in Kazakh.

What is the salt of hydrochloric acid?

What is the element used for disinfection?

What is the substance consisting of two elements, one of which is oxygen?

How is the element type change called?

What is the lightest element?

2. Carbon is a metal or a____ (non-metal)

Iron, copper, sodium are ___ (metals)

Oxygen, silicon, carbon are __ (non-metals)

Most of elements in Periodic Table are (metals)

Sulfur is a ___ (non-metal)

To determine the effectiveness of working on a glossary during the course of teaching chemistry in English, a glossary «Electronegativity. A covalent bond» was given to the pupils in two languages:

Electronegativity is the ability of atoms to pull electrons towards themselves.

A chemical bond is the formation of a bond of chemical elements interacting with each other.

Cation is a positively charged particle.

Anion is a negatively charged particle.

An ion is a charged atom or group of atoms.

A covalent bond is a type of a chemical bond that involves the sharing of electron pairs between atoms.

Non polar bond is a bond formed between chemical elements with the same electronegativity.

A polar bond is a type of bond formed between atoms of various nonmetals.

During the lesson conducted using the glossary, the pupils learned to be more careful and to express their ideas in a short and easy way. The glossary was prepared in two languages which allowed pupils to remember the terms and definitions of chemistry in English. The results were positive. Initially, it was difficult for the pupils since they had not been accustomed to working on the glossary prepared in two languages. Later, they realized that the lesson was interesting and they also could benefit from using the time efficiently. The effectiveness of the glossary in teaching chemistry in English was determined by the survey results taken from the pupils.

The effectiveness of the text composed on the English-language basis in teaching chemistry in English was also investigated by the Jigsaw method alongside the CLIL method [17].

An acid is a substance that produces $\mathrm{H}^{+}(\mathrm{aq})$ ions when dissolved in water.

The commonest acids in the laboratory are sulfuric acid $\left(\mathrm{H}_{2} \mathrm{SO}_{4}\right)$, hydrochloric acid $(\mathrm{HCl})$ and nitric acid $\left(\mathrm{HNO}_{3}\right)$. These are known as the mineral acids. Another common acid is acetic acid (acetic acid, $\mathrm{CH}_{3} \mathrm{COOH}$ ), a smelly liquid that boils at $118^{\circ} \mathrm{C}$. Acetic acid is the chemical that gives vinegar its sour taste.

A base is a substance that reacts with an acid in solution producing only water and salt.

Generalizing:

acid + base $\rightarrow$ salt + water

This reaction is known as neutralization.

An alkali is a base that dissolves in water. A solution of an alkali contains the hydroxide ion, $\mathrm{OH}^{-}(\mathrm{aq})$.

Alkalis are usually hydroxides of metals. The common alkalis are the hydroxides of calcium, potassium and sodium. They are all are ionic solids which completely dissociate into ions in water.

Ammonia solution is also regarded as an alkali because it contains the hydroxide ion. 
Bases which are insoluble in water include the oxides of metals such as magnesium oxide $\left(\mathrm{Mg}^{2+}, \mathrm{O}^{2-}\right)$ and copper (II) oxide $\left(\mathrm{Cu}^{2+}, \mathrm{O}^{2-}\right)$ and organic compounds (compounds based on carbon) which contain nitrogen atoms such as propylamine $\left(\mathrm{C}_{3} \mathrm{H}_{7} \mathrm{NH}_{2}\right)$ [18].

The pupils were asked questions about the text and their acquisition of the text given in English which was determined (Table 1).

\section{English language based text questions}

\begin{tabular}{|l|l|l|}
\hline \multicolumn{1}{|c|}{ Questions } & \multicolumn{1}{|c|}{ Yes } & No \\
\hline Is the topic about bases? & & \\
\hline Were alkaline metals written? & & \\
\hline Are there any insoluble bases? & & \\
\hline Are Arabic numerals used in writing the bases? & & \\
\hline Was the work conducted through classifying bases? & & \\
\hline Is it explained why alkali metals are caustic? & & \\
\hline
\end{tabular}

The CLIL method was applied in continuity with the heuristic method of teaching calculations by using English in chemistry classes [19]. During the lesson some calculations were done only after the new topic had been explained and the new words related to the lesson topic had been written in Kazakh and English.

Firstly, calculations on the first topic of «Solutions» were performed in Kazakh. solution.

1. If $20 \mathrm{~g}$ of the substance is in $190 \mathrm{~g}$ of solution, find the mass fraction of the dissolved substance in this

2. How much salt and water are needed to make $300 \mathrm{~g}$ of a $35 \%$ solution?

3. Calculate the mass fraction of the dissolved substance in the solution formed when $45 \mathrm{~g}$ of salt is dissolved in $220 \mathrm{ml}$ of water.

4. How many substances should be dissolved in $250 \mathrm{ml}$ of water to prepare a $12 \%$ solution by mass?

5. What is the mass fraction of $74 \mathrm{~g}$ of table salt dissolved in $274 \mathrm{~g}$ of solution?

The work with English terminology was carried out before starting the calculations in English. The terminology found in the calculation was used to help the pupils to understand problems in English and to solve them (Table 2).

Table 2

Terms used in the calculation

\begin{tabular}{|l|l|}
\hline Массалық үлес & Mass percentage \\
\hline Молярлық концентрация & Molar concentration \\
\hline Көбейту & To multiply \\
\hline Бөлу & Divide \\
\hline Дистильденген су & Distilled water \\
\hline Қатынас & Proportion \\
\hline Байланысты болу & To depend on \\
\hline Берілгені & Given \\
\hline Табу керек & To find \\
\hline Шығаружолы & Way to solve \\
\hline Ерігензат & Solute \\
\hline Еріткіш & Solvent \\
\hline Ерігіштік & Solubility \\
\hline Қанықпаған & Unsaturated \\
\hline Қаныққан & Saturated \\
\hline Аз ериді & Slightly soluble \\
\hline
\end{tabular}

The problems given in English were solved after getting acquainted with the terms necessary for doing calculations.

1. $20 \mathrm{~g}$ of sodium reacts with nitric acid. Find the mass of sodium nitrate.

2. $3.9 \mathrm{~g}$ of potassium reacts with oxygen. Find the mass of potassium oxide.

$3.25 \mathrm{~g}$ of salt is dissolved in $75 \mathrm{~g}$ of water. What is the mass percentage of salt? 
4. Find the mass of sodium carbonate to prepare $50 \mathrm{~g}$ of $7 \%$ solution?

$5.25 \mathrm{~g}$ of salt was added to $200 \mathrm{~g}$ solution. What is the mass percentage of salt?

6 . How much sodium nitrate should be taken to prepare $15 \mathrm{~g}$ of $30 \%$ solution?

The increase in the pupils' thinking ability was observed while doing chemistry calculations in English.

\section{Results and Discussion}

With a view to determining the glossary effectiveness in a pedagogical experiment conducted using the CLIL method in the chemistry class, the learners were taken a questionnaire consisting of the following questions:

1. Did you like the lesson?

2. Has the glossary helped you to understand the text given in two languages?

3. Do you want to work with a glossary in the future?

4. Have you ever worked with a glossary?

5 . Did you face any challenges in working with the glossary?

Most of the surveyed pupils supported the glossary efficiency in teaching chemistry in English, while a few of them did not (Fig. 1). The survey result revealed that the pupils had a desire to work on a glossary and working on the glossary had a positive impact on learning outcomes.

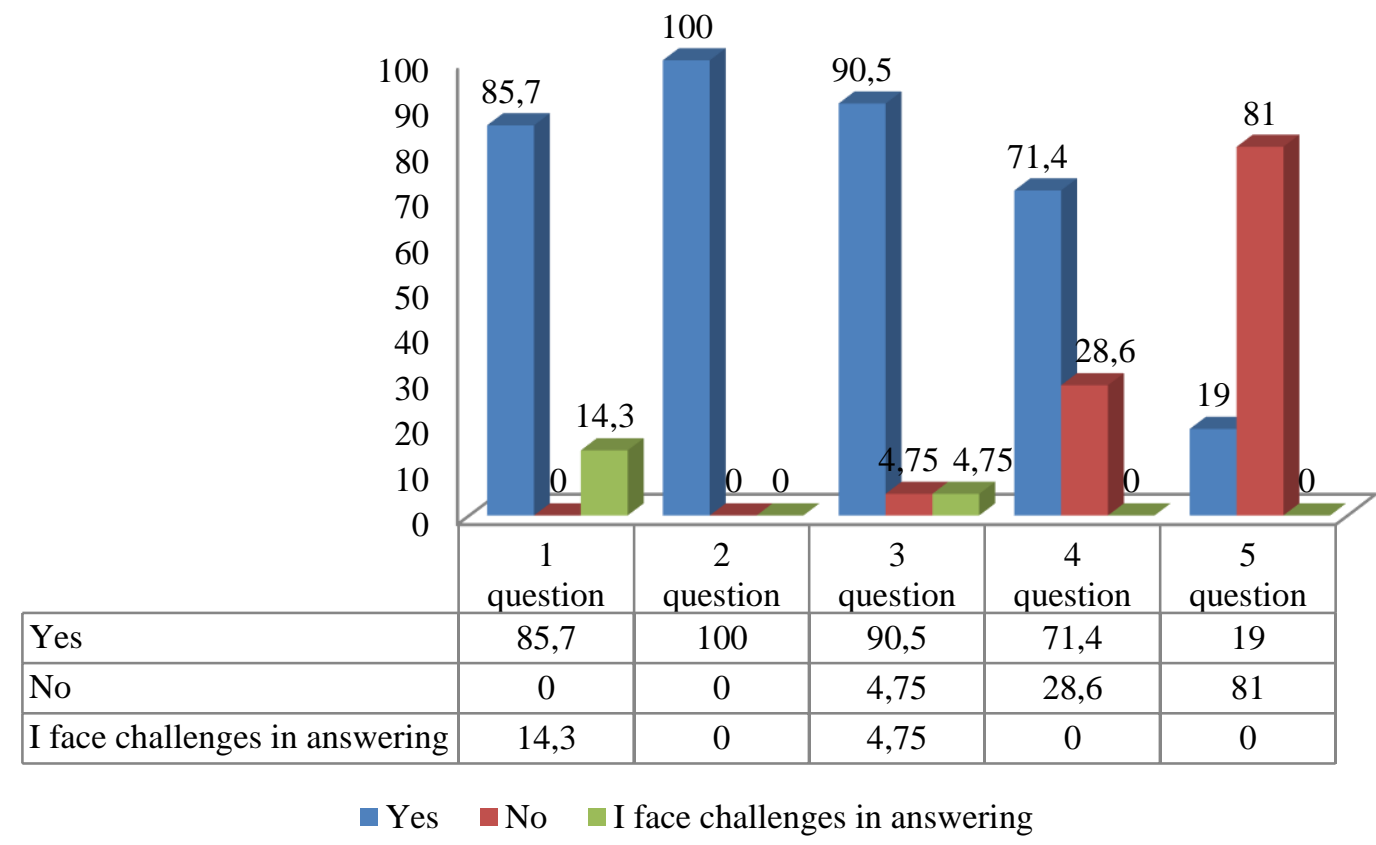

Figure 1 . The survey results to determine the glossary work effectiveness

The pupils were surveyed to determine the effectiveness of working on the text in English, which was used to develop language skills in integrated chemistry teaching. The questionnaire consisted of the following questions:

1. Did working hard with «an English text» exercise help you to develop your English language skills?

2. Have you ever worked with «an English text» exercise before?

3. Did you enjoy working with «the English text» exercise?

4. Was it fun to work with «the English text» exercise?

5. Did the English text help you to understand the lesson better?

Almost half of the pupils who were surveyed gave a negative answer to the question «Have you ever worked with an English text exercise before?» This indicates that English has not been used before in teaching chemistry. The rest of the questionnaire answers indicates that most learners liked working on the English text and understood the lesson (Fig. 2). 


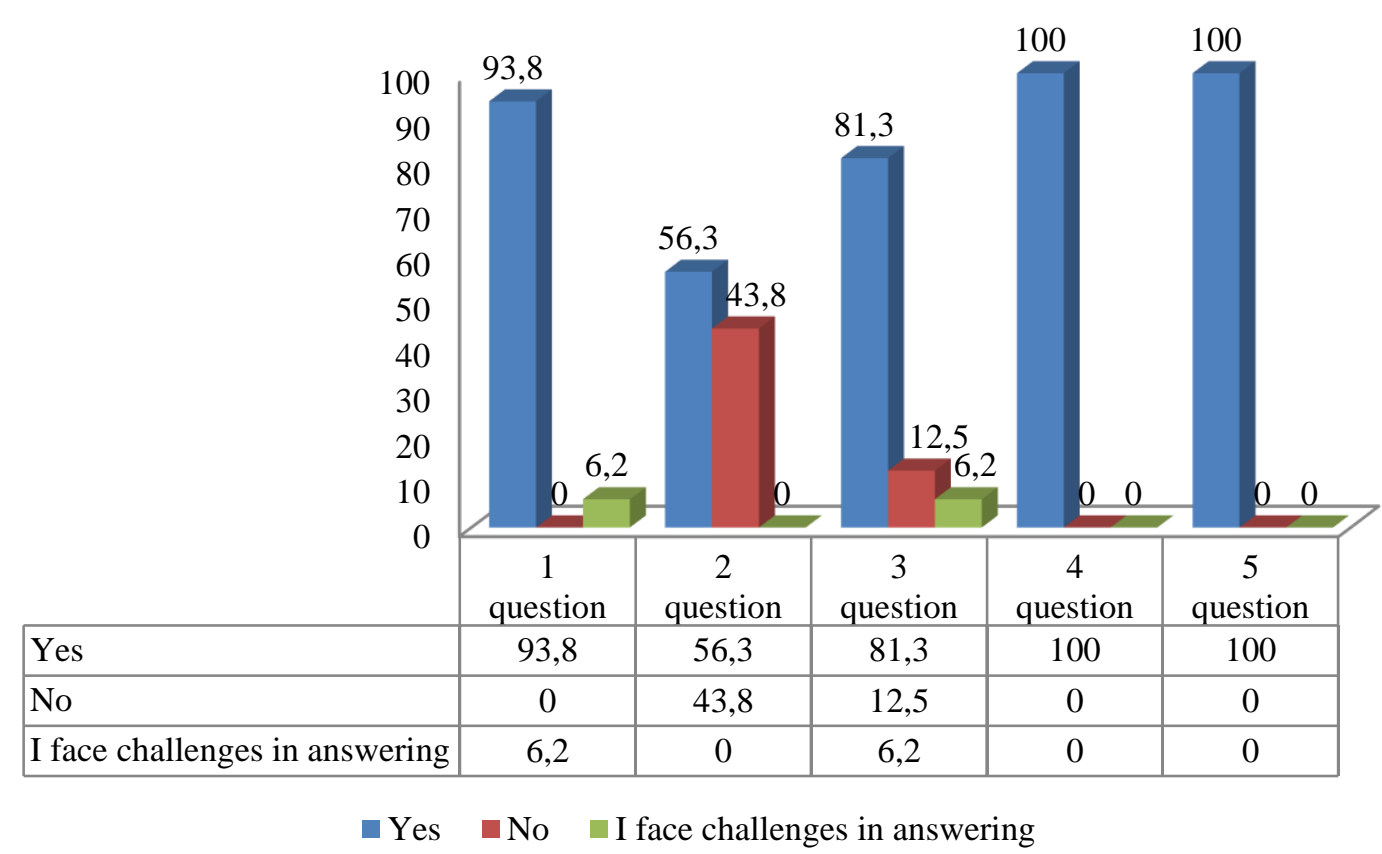

Figure 2. The survey results to determine the effectiveness of working on a text in English

The pupils were asked to complete the summative assessment (SA) according to sections 1 and 2 to identify how their progression in knowledge, skills, and understanding related subject content is changed. The summative assessment on the first section was taken before the experiment, i.e. when used traditional teaching strategies. In the second section, the summative assessment was obtained after application CLIL method teaching in the Chemistry classroom. The maximum score of the summative assessment task for each section was 15 points. 21 pupils took part in the tasks. The SA were used to evaluate effectiveness of the CLIL method.

By analyzing the pre- and post-experiment results it was observed upward in pupils' learning outcomes after using the CLIL teaching method in the class. Before the experiment, the summative assessment average score of the pupils for the first section was 9.76 points. When the experimental group was taught through the CLIL method, the average score of the pupils for the second section reached 12.85 points. (Fig. 3). The academic performance of pupils in this group is explained by the fact that chemistry was taught in English in the continuity of the traditional method and the CLIL method.

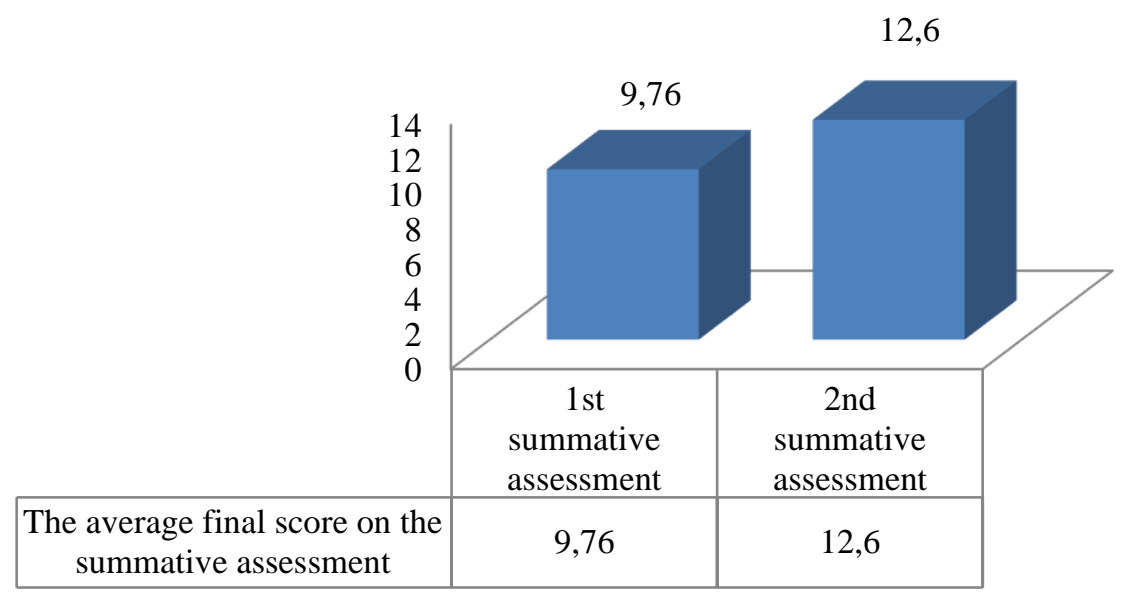

The average final score on the summative assessment

Figure 3. Results of the summative assessment on sections 1 and 2 on the mastery of the lesson materials 
The peculiarity of teaching chemistry in English is to increase pupils' interest in chemistry and English by using active teaching methods based on modern teaching idea. To implement this idea, the chemistry was taught in English by applying the CLIL method for the first time in the specialized boarding school named after N. Ondasynov in Turkistan. The study results allowed to change the practice of teaching the subject. The use of CLIL methods was expanded to increase pupils' interest in chemistry and to improve their comprehension of chemical terminology in English. The CLIL teaching method was applied in combination with active methods («Jigsaw», «Five Ws») and traditional methods which contributed not only assimilation and understanding of subject content but also the development of critical thinking, improving vocabulary and language skills of the pupils. Implementation of the CLIL method teaching in Chemistry classroom based on the continuity of traditional methods and new technologies allowed the pupils to acquire chemistry in English thoroughly.

\section{Conclusions}

The application of the CLIL teaching method in the Chemistry classroom increases learners' interest in both subject and language context. At each lesson the pupils had the opportunity to access basic concepts and skills relating to the subject content, to express their thoughts clearly and to enhance their knowledge. As a result of the proposed research, it was proved that the implementation of CLIL teaching methodology develop pupils' progression in knowledge, skills, and understanding Chemistry subject content. It based on the principle to support and improve the pupils' thinking process by teaching Chemistry subject content through English. The survey results revealed formation not only content-learning outcomes but also language-learning outcomes and the effectiveness of working on terminology, glossary, an English-language based text and calculations in integrated teaching. As for features of teaching Chemistry in English, the CLIL approaches proved to be effective in developing subject competencies, develop multilingual interest and attitudes, increase motivation in learning, interest in the subject and increased academic performance.

The integrated chemistry course takes teachers a lot of time to prepare for the lesson since teaching chemistry in another language requires much attention to be drawn to the subject, as well as the language. However, the integrated approach towards teaching chemistry is more successful than the traditional one.

\section{References}

1 Дорожная карта развития трехъязычного образования на 2015-2020 годы. Утверждена совместным приказом и.о. министра образования и науки Республики Казахстан от 5 ноября 2015 года № 622, министра культуры и спорта Республики Казахстан от 9 ноября 2015 года № 344 и министра по инвестициям и развитию Республики Казахстан от 13 ноября 2015 года № 1066. — URL: https://www.vkgu.kz/sites/default/files/files/poliyaz_obraz/doroj_kart_razv_trehyazich_obraz_2015_2020_ru.pdf

2 Belyaeva I.G. Analysis of Innovative Methods' Effectiveness in Teaching Foreign Languages for Special Purposes Used for the Formation of Future Specialists' Professional Competencies / I.G. Belyaeva, E.A. Samorodova, O.V. Voron, E.S. Zakirova// Educ. Sci. — 2019. - Vol. 9, No. 3. - P. 171. DOI: 10.3390/educsci9030171

3 Bokut E.L. Project method and interdisciplinary connections in university students teaching («Foreign language» and «Family psychological support») / E.L. Bokut, O.G. Serebryantzeva // Междунар. науч.-исслед. журн. — 2016. — № 2(44), Ч. 4. — Р. 107111. DOI: $10.18454 /$ IRJ.2016.44.059

4 Nargis N. Optimizing EFL learners' communicative competence through short movie project / N. Nargis, L. Armelia // Asian EFL Journal. — 2018. - Vol. 20, No. 5. - P. 201-208.

5 Fesenko O.P. Cases in methods of teaching Russian as a foreign language / O.P. Fesenko, E.V. Fedyaeva, V.V. Bestsennaya // Lang. Cult. — 2017. — P. 104-117. DOI: 10.17223/24109266/9/12

6 Hsu W. Harvard Business school (HBS) case method to teaching English for business communication / W. Hsu // Educ. Linguist. Res. - 2016. - Vol. 2, No. 2. - P. 95-114. ISSN 2377-1356. DOI: 10.5296/elr.v2i2.10192

7 Nechayuk I.A. Active methods as optimization model for teaching English for special purposes / I.A. Nechayuk // Interact. Sci. — 2017. — Vol. 2. - P. 96-99. DOI 10.21661/r-117837, ISSN 2414-9411

8 Unin N. Brainstorming as a Way to Approach Student-centered Learning in the ESL Classroom / N. Unin, P. Bearing // Procedia Soc. Behav. Sci. — 2016. — Vol. 224. - P. 605-612. DOI: 10.1016/j.sbspro.2016.05.450

9 Калюжная Т.В. Деловая игра как способ реализации компетентностного подхода при изучении иностранного языка в вузе / Т.В. Калюжная, Е.В. Скоробогатова, А.В. Власова // Вестн. Кемеров. гос. ун-та. — 2015. — Т. 3, № 2. - С. 52-54.

10 Rodomanchenko A. Roundtable Discussion in Language Teaching: Assessing Subject Knowledge and Language Skills / A. Rodomanchenko // J. Lang. Educ. — 2017. — Vol. 3. — P. 44-51. DOI:10.17323/2411-7390-2017-3-4-44-51

11 Bidenko L. Implementing audio-lingual method to teaching Ukrainian as a foreign language at the initial stage / L. Bidenko, G. Bespalova // Adv. Educ. — 2017. — Vol. 3. — P. 23-27. DOI: 10.20535/2410-8286.82711

12 Xabier S.I. Innovations and Challenges in CLIL Implementation in Europe / S.I. Xabier // Theory Into Practice. — 2018. — Vol. 57, No 3. - P. 185-195. 
13 Popova N.V. Constraints of Communicative Approach to Language Teaching in RussianTertiary Education / N.V. Popova, E.K. Vdovina // Proceedings of the 18th PCSF 2018 - Professional Culture of the Specialist of the Future. - 2018. - P. $1325-1336$. https://dx.doi.org/10.15405/epsbs.2018.12.02.142

14 Cambridge English. Teaching Knowledge Test (TKT). Content and Language Integrated Learning (CLIL). Handbook for Teachers. - 2016. - P. 31.

15 Recatalá D. Using Active Learning Methodologies in Physical Chemistry in CLIL Contexts Multidisc / D. Recatalá // Mult. J. Edu. Soc\& Tec. Sci. - 2016. - Vol. 3, No. 1. — P. 71-83. http://dx.doi.org/10.4995/muse.2016.3696

16 Жетписбаева Б.А. К вопросу о методическом обеспечении трёхъязычного образования / Б.А. Жетписбаева, А.Е. Кубеева // Вестн. Караганд. ун-та. Сер. Педагогика. — 2017. — С. 138-145.

17 Nusrath A. Jigsaw Classroom: Is it an Effective Method of Teaching and Learning? Student's Opinions and Experience / A. Nusrath, S. Dhananjaya, N. Dyavegowda, R. Arasegowda, A. Ningappa, R. Begum // Journal of Clinical \& Diagnostic Research. - 2019. - Vol. 13, Iss. 2. - P. 1-4.

18 Lewis R. Chemistry. Third edition / R. Lewis, W. Evans. - Palgrave Macmillan, 2006. ISBN-13: 978-0-230-00011-7, ISBN-10: 0-230-00011-8

19 Nacu D. Designing for 21st century learning online: a heuristic method to enable educator learning support roles / D. Nacu, C.K. Martin, N.Pinkard // ETR\&D, - 2018. — P. 1029-1049. DOI: 10.1007/s11423-018-9603-0

\title{
Р.Н. Нұрділлаева, А.Ж. Байсалова, Ғ.Ө. Жұман
}

\section{Химияны ағылшын тілінде оқытудың ерекшелігі: дәстүрлі және жаңа технология сабақтастығы}

\begin{abstract}
Мақалада орта мектепте химия пәнін ағылшын тілінде оқытудың дәстүрлі және жаңа технологиялардың сабақтастығы туралы зерттеу нәтижелері сипатталған. Окушылардың химия пәніне деген қызығушылықтарын арттыру және білімін жетілдіру үшін түрлі дәстүрлі әдістермен бірге қазіргі жаңа технология пәнімен тілді кіріктіре оқыту — CLIL әдісі зерттелген. Зерттеу өткізу кезінде сыныптағы окушылардың химия пәнін оқу кезіндегі оқушылардың ынтасына, білім деңгейлеріне және тілді меңгеру қабілеттеріне ерекше назар аударылған. Химия пәнін ағылшын тілінде оқытуда жаңа әдіс-тәсілдерді тиімді пайдалану жолдары қарастырылып, жаңа оқу бағдарламасы негізінде химия пәнін ағылшын тілінде байланыстыра оқыту тәжірибесі зерделенген. CLIL технологиясын сабақ барысында қолдану үшін терминология, глоссарий, ағылшын тіліндегі мәтінмен жұмыс және есептеулер жүргізу әдістемесі таңдалған. Химия сабағында CLIL технологиясын қолданудың тиімділігін анықтау үшін мектеп оқушыларынан сауалнама алынып, педагогикалық бақылау жүргізілген. Жүргізілген сауалнама нәтижелері бойынша химия пәнін ағылшын тілінде оқытудың ұтымдылығына көз жеткізілген. Терминология және глоссариймен жұмыс жасау барысында терминдерді сабақта қолдана отырып, оқушылардың химия пәні бойынша сөздік қоры көбейіп, пәнге деген қызығушылықтары артқан. Мәтінмен жұмыс барысында окушылардың ағылшын тілінде сөйлеу, ойлау дағдысы қалыптасқан. Пән мен тілді кіріктіре оқытуда CLIL әдісін қолдану оқушыларға пән бойынша ақпарат алумен қатар, тілді меңгеруге де мүмкіндік берді.
\end{abstract}

Кілт сөздер: CLIL әдісі, химияны ағылшын тілінде оқыту, пән мен тілді кіріктіре оқыту, глоссарий, терминология, ағылшын тіліндегі мәтінмен жұмыс, CLIL технологиясы, сауалнама, дәстүрлі әдіс.

\section{Р.Н. Нурдиллаева, А.Ж. Байсалова, Г.О. Жуман}

\section{Особенности преподавания химии на английском языке: преемственность традиционных и новых технологий}

\begin{abstract}
В статье описаны результаты исследования о преемственности традиционных и новых технологий в преподавании химии на английском языке в средней школе. С целью повышения интереса учащихся к предмету и совершенствования знаний по химии, наряду с различными традиционными методами, был изучен метод CLIL (интегрированное обучение предмета на языке современной технологии). В ходе проведения исследования особое внимание было уделено мотивации учащихся к изучению химии, уровню знаний и способности овладения языка. Рассмотрены пути эффективного использования новых методов и приемов в преподавании химии на английском языке по новой учебной программе. Для использования технологии CLIL в ходе урока были выбраны терминология, глоссарий, работа с текстами на английском языке и методика проведения вычисления. Для определения эффективности применения технологии CLIL на уроках химии был проведен опрос учащихся и педагогический контроль. По результатам опроса была доказана эффективность преподавания химии на английском языке. В ходе работы над терминологией и глоссарием наблюдается увеличение словарного запаса учащихся по химии и повышение интереса к предмету. При работе с текстом у учащихся сформировались навыки устной речи, мышления на английском языке. Интеграция предметного и языкового обучения позволила учащимся не только получить информацию по предмету, но и освоить язык.
\end{abstract}


Ключевые слова: метод CLIL, обучение химии на английском языке, интегрированное обучение предмета и языка, глоссарий, терминология, работа с текстом на английском языке, технология CLIL, опрос, традиционный метод.

\section{References}

1 Dorozhnaia karta razvitiia trekhiazychnoho obrazovaniia na 2015-2020 hody. Utverzhdena sovmestnym prikazom i.o. ministra obrazovaniia i nauki Respubliki Kazakhstan ot 5 noiabria 2015 hoda № 622, ministra kultury i sporta Respubliki Kazakhstan ot 9 noiabria 2015 hoda № 344 i ministra po investitsiiam i razvitiiu Respubliki Kazakhstan ot 13 noiabria 2015 hoda № 1066 [The road map of trilingual education for 2015-2020 years. Approved by joint Order of the acting Ministry of Education and Science of the Republic of Kazakhstan dated November 5, 2015, No. 622, Ministry of Culture and Sports of the Republic of Kazakhstan dated November 9, 2015, No. 344 and Ministry of Investment and Development of the Republic of Kazakhstan dated November 13, 2015, No. 1066]. www.vkgu.kz Retrieved from https://www.vkgu.kz/sites/default/files/files/poliyaz_obraz/doroj_kart_razv_trehyazich_obraz_2015_2020_ru.pdf [in Russian].

2 Belyaeva, I.G., Samorodova, E.A., Voron, O.V. \& Zakirova, E.S. (2019). Analysis of Innovative Methods' Effectiveness in Teaching Foreign Languages for Special Purposes Used for the Formation of Future Specialists' Professional Competencies. Educ. Sci., 9, 171; DOI:10.3390/educsci9030171

3 Bokut, E.L., \& Serebryantzeva, O.G. (2016). Project method and interdisciplinary connections in university students teaching («Foreign language» and «Family psychological support»). International Research Journal, 2(44), Pt. 4, 107-111. DOI: 10.18454/IRJ.2016.44.059

4 Nargis, N., \& Armelia, L. (2018). Optimizing EFL learners' communicative competence through short movie project. Asian EFL J., 20, 5, 201-208.

5 Fesenko, O.P., Fedyaeva, E.V., \& Bestsennaya V.V. (2017). Cases in methods of teaching Russian as a foreign language. Lang. Cult., 104-117. DOI: 10.17223/24109266/9/12,104-117.

6 Hsu, W. (2016). Harvard Business school (HBS) case method to teaching English for business communication. Educ. Linguist. Res., 2, 2, 95-114. DOI: 10.5296/elr.v2i2.10192, ISSN 2377-1356

7 Nechayuk, I.A. (2017). Active methods as optimization model for teaching English for special purposes. Interact. Sci., 2, $96-$ 99. DOI 10.21661/r-117837, ISSN 2414-9411 96-99.

8 Unin, N., \& Bearing, P. (2016). Brainstorming as a Way to Approach Student-centered Learning in the ESL Classroom. Procedia Soc. Behav. Sci., 224, 605-612.

9 Kalyuzhnaya, T.V., Skorobogatova, E.V., \& Vlasova, A.V. (2015). Delovaia ihra kak sposob realizatsii kompetentnostnoho podkhoda pri izuchenii inostrannoho yazyka $\mathrm{v}$ vuze [Business role-play as a means of competence approachimplementation in teaching the English language at higher education institutions]. Vestnik Kemerovskoho hosudarstvennoho universiteta - Bulletin of the Kemerovo State University, 3, 2, 52-54 [in Russian].

10 Rodomanchenko, A. (2017). Roundtable Discussion in Language Teaching: Assessing Subject Knowledge and Language Skills. J. Lang. Educ., 3, 44-51. doi:10.17323/2411-7390-2017-3-4-44-51.

11 Bidenko, L., \& Bespalova, G. (2017). Implementing audio-lingual method to teaching Ukrainian as a foreign language at the initial stage. Adv. Educ., 3, 23-27. DOI: 10.20535/2410-8286.82711

12 Xabier, S.I. (2018). Innovations and Challenges in CLIL Implementation in Europe. Theory into Practice, 57, 3, $185-195$.

13 Popova, N.V., \& Vdovina, E.K. (2018). Constraints of Communicative Approach to Language Teaching in Russian Tertiary Education. Proceedings of the 18th PCSF 2018 - Professional Culture of the Specialist of the Future, 1325-1336. https://dx.doi.org/10.15405/epsbs.2018.12.02.142 ISSN: 2357-1330

14 Cambridge English. Teaching Knowledge Test (TKT). Content and Language Integrated Learning (CLIL). (2016). Handbook for Teachers.

15 Recatalá, D. (2015) Using Active Learning Methodologies in Physical Chemistry in CLIL Contexts Multidisc. Journ. for Educ. Soc. and Techn. Sci., 3, 1, 71-83. http://dx.doi.org/10.4995/muse.2016.3696, EISSN: 2341-2593.

16 Zhetpisbayeva, B.A., \& Kubeeva, A.E. (2017). K voprosu o metodicheskom obespechenii trekhiazychnoho obrazovaniia [On the issue of methodological support for trilingual education]. Vestnik Karahandinskoho universiteta. Seriia Pedahohika - Bulletin of the Karaganda University. Pedagogy series, 138-145 [in Russian].

17 Nusrath, A., Dhananjaya, S., Dyavegowda, N., Arasegowda, R., Ningappa, A., \& Begum, R. (2019). Jigsaw Classroom: Is it an Effective Method of Teaching and Learning? Student's Opinions and Experience. Journal of Clinical \& Diagnostic Research, 13, $2,1-4$.

18 Lewis, R., \& Evans, W. (2006). Chemistry. Third edition. ISBN-13: 978-0-230-00011-7 ISBN-10: 0-230-00011-8

19 Nacu, D., Martin, C.K., \& Pinkard, N. (2018). Designing for 21st century learning online: a heuristic method to enable educator learning support roles. ETR\&D, 1029-1049. DOI: 10.1007/s11423-018-9603-0 